\title{
COMPARATIVE ANALYSIS OF MULTIPLE SLEEP LATENCY TESTS (MSLT) PARAMETERS AND OCCURRENCE OF DREAMING IN PATIENTS WITH DAYTIME SLEEPINESS OF NARCOLEPTIC AND NON-NARCOLEPTIC ORIGIN
}

\author{
Eduardo Siqueira Waihrich'1, Raimundo Nonato Delgado Rodrigues², \\ Henrique Aragão Silveira ${ }^{1}$, Fernando da Fonseca Melo Fróes ${ }^{1}$, \\ Guilherme Henrique da Silva Rocha ${ }^{1}$
}

\begin{abstract}
Objective: To compare MSLT parameters in two groups of patients with daytime sleepiness, correlated to the occurrence and onset of dreams. Method: Patients were submitted to the MSLT between January/1999 and June/2002. Sleep onset latency, REM sleep latency and total sleep time were determined. The occurrence of dreams was inquired following each MSLT series. Patients were classified as narcoleptic (N) or non-narcoleptic (NN). Results: Thirty patients were studied, 12 were classified as narcoleptics (N g roup; 40\%), while the remaining 18 as non-narcoleptic (NN group; 60\%). Thirty MSLT were performed, resulting in 146 series. Sleep was detected in 126 series (86\%) and dreams in 56 series (44.44\%). Mean sleep time in the $\mathrm{N}$ group was $16.0 \pm 6.3 \mathrm{~min}$, while $10.5 \pm 7.5 \mathrm{~min}$ in the NN group $(p<0.0001)$. Mean sleep latency was $2.0 \pm 2.2 \mathrm{~min}$ and $7.2 \pm 6.0 \mathrm{~min}$ in the $\mathrm{N}$ and NN group, respectively $(p<0.001)$. Mean REM sleep latency in the $\mathrm{N}$ group was $3.2 \pm 3.1 \mathrm{~min}$ and $6.9 \pm 3.7 \mathrm{~min}$ in the NN group $(p=0.021)$. Dreams occurred in $56.9 \%$ of the $\mathrm{N}$ group series and $28.4 \%$ in that of the NN group ( $p=0.0009)$. Dream frequency was detected in $29.8 \%$ and $75 \%$ of the NREM series of the $N$ and NN groups, respectively $(p=0.0001)$. Conclusion: Patients from the N group, compared to the NN group, slept longer and earlier, demonstrated a shorter REM sleep onset and greater dreamfrequency. NN patients had a greater dream frequency in NREM series. Thus, the occurrence of dreams during NREM in the MSLT may contribute to diff e rentially diagnose narcolepsy and daytime sleepiness.
\end{abstract}

KEY WORDS: narcolepsy, daytime sleepiness, multiple sleep latency test, dreams, REM.

\begin{abstract}
Estudo comparativo de parâmetros de testes de latências múltiplas do sono (TLMS) e ocorrência de sonhos em pacientes hipersones narcolépticos e não-narcolépticos

RESUMO - Objetivo: Comparar variáveis do TLMS em dois grupos de pacientes hipersones e correlacionar p resença e momento de ocorrência de sonhos. Método: Os pacientes foram submetidos a TLMS entre janeiro de 1999 e junho de 2002. Analisou-se a média das latências de sono, latências de sono REM e tempo total de sono. A presença de sonhos foi inquirida após cada série. Classificou-se os pacientes em narcolépticos (N) e não-narcolépticos (NN). Resultados: Do total de 30 pacientes, 12 foram classificados no g rupo N (40\%) e 18 no NN (60\%). Dos 30 TLMS foram obtidas 146 séries. Houve sono em126 (86\%) e sonho em $56(44,44 \%)$. O tempo médio de sono no grupo $N$ foi $16,0 \pm 6,3 \mathrm{~min}$ e no $N N 10,5 \pm 7,5 \mathrm{~min}(p<0,0001)$. A latência média de sono no grupo $N$ foi $2,0 \pm 2,2 \min$ e no $N N 7,2 \pm 6,0 \min (p<0,001)$. A latência média do sono REM no $\mathrm{N}$ foi $3,2 \pm 3,1 \mathrm{~min}$ e no $\mathrm{NN} 6,9 \pm 3,7 \mathrm{~min}(p=0,021)$. Houve sonhos em $56,9 \%$ das séries do grupo $\mathrm{N}$ e $28,4 \%$ do NN ( $p=0,0009$ ). A freqüência de sonhos em séries NREM no $N$ foi $29,8 \%$ e no NN $75 \%$ ( $p=$ 0,0001 ). Conclusão: Os pacientes do grupo $\mathrm{N}$ dormiram mais e mais rapidamente, apresentaram REM mais precocemente e maior freqüência de sonhos que os NN. Estes apresentaram maior freqüência de sonhos em séries NREM. A presença de sonhos em NREM no TLMS pode contribuir no diagnóstico diferencial entre narcolepsia e hipersonia diurna.
\end{abstract}

PALAVRAS-CHAVE: narcolepsia, hipersonia, teste de latências múltiplas do sono, sonhos, REM.

1MD, Hospital Universitário de Brasília, Brasília DF - Brazil (UnB); ${ }^{2}$ Neurologista, MD, PhD, Chefe de Serviço, UnB. Received 16 May 2006, received in final form 28 July 2006. Accepted 19 September 2006.

Dr. Eduardo Siqueira Waihrich - SQS 306 / Bloco B / Apartamento 403 / Asa Sul - 70353-020 Brasília DF - Brasil. E-mail: eduwaihrich@ig.com.br 
Narcolepsy is a chronic neurological disorder, mainly characterized by uncontrollable sleep attacks and cataplexy, although hypnagogic hallucinations and sleep paralysis may also occur ${ }^{1-5}$. In spite of its low prevalence $(0.02 \%)^{2,3}$, this disorder is one of the most debilitating diseases within Sleep Medicine (Hypniatry), leading to professional problems, social stigmas and risks to the patients' physical integrity2-5. Narcolepsy is highly under-diagnosed, with a 10-15 year time lag between symptom onset and definite diagnosis ${ }^{2,4}$. Thus, accurate early identification of these patients is very important. In this sense, the Multiple Sleep Latency Test (MSLT) has proved to be and important tool in diffe rentially diagnosing daytime sleepiness, one of the main complaints within Hypniatry ${ }^{1-6}$. From a physiopathological perspective, na rcolepsy characterizes a multi-level dysfunction of the activation and control mechanisms of REM sleep, to which the absence of the thalamic peptide hypocretin is an important contributing factor ${ }^{7,8}$.

REM sleep, on the other hand, is mainly characterized by diffuse muscle atonia (except for the diaphragm and extrinsic ocular muscles), intense cerebral activity and occurrence of dreams $\mathrm{s}^{6,9-14}$. As dreams are initiated by a complex synaptic network, the study of its patterns is of great scientific interest ${ }^{6,9,14,15}$. Although the functions of dreams have not been fully elucidated, qualitative and quantitative differences between REM and NREM dreams have been described $^{13-18}$. In general, more complex, vivid and bizarre dreams are reported during REM sleep ${ }^{12,13,15,18}$. As nume raus sleep disorders, including narcolepsy, characteristically modify dream patterns or coexist with oniric hallucinations ${ }^{3,4,14}$, a better functional and etiological understanding of the dream-related mechanisms may provide a more efficient clinical and therapeutic approach to these diseases $3,4,14,19,20$. This study thus aimed at analyzing specific MSLT parameters in two distinct groups of patients with a general complaint of excessive daytime sleepiness, studying the frequency and moment of dreaming onset.

\section{METHOD}

An analytical case-controlled investigation was conducted on data obtained from patient re cords who had been submitted to the MSLT as part of the investigation for excessive daytime sleepiness complaints. The patients selected we re young adults with complaints of excessive daytime sleepiness, without any previous treatment. The study was held at the Sleep Laboratory of the University Hospital of Brasilia, Brazil, between January/1999 and June/2002. Free and informed consent was obtained from all subjects.
For the MSLT, the patient was allowed 4 or 5 naps, at 2-h interval, with a maximum 20-min duration (corresponding to one series) ${ }^{2}$. Electroencephalograms (EEG) were recorded on three channels (C3-A1, C4-02, F3-O2) with electrodes positioned according to the 10-20 International System. A right and left electro-oculogram and an eletromyogram (mentonian electrodes) were also performed.

Patients were classified as narcoleptic- or non-narcoleptic-compatible using the diagnostic criteria of the International Classification of Sleep Disorders, revised version of 2005 (ICSD-2005) 1,4,21. Patients presenting mean sleep latency under 5-min, and 2 or more series with REM sleep, we re considered as being narcoleptics $(\mathrm{N})$ and the remaining subjects as non-narcoleptics (NN). Mean sleep latencies under 5-min, associated to 2 or more REM sleep episodes, a re high suggestive of narcolepsy (sensitivity $70 \%$, specificity $97 \%)^{2,3}$. Following each MSLT series, the patient was inquired as to whether he/she had dreamt in the preceding series.

Patients and series were also divided into groups according to the presence or absence of dreams and total sleep time. Then absolute NREM and REM sleep latencies were compared between series with and without the occurrence of dreams. The frequency of dreams reported was also compared between NREM and REM series. Tests that were interrupted without a minimum of 4 series, with a total sleep time greater than 20-min for one given series or with an inadequate EEG were excluded.

The study was submitted to and approved by de Ethics Committee of our Institution.

Statistical analyses were performed using the exact Fisher and Mann-Whitney tests. Statistical significance was set at $\mathrm{p}<0.05$.

\section{RESULTS}

MSLT was performed on 82 patients during the study period 30 of which fulfilled the selection criteria, being $23(77 \%)$ men and 7 (23\%) women, with the mean age of $31,6 \pm 6.87(p=0,6)$. Twelve patients $(40 \%)$ were classified as narcoleptics $(\mathrm{N})$ and $18(60 \%)$ as non-narcoleptics (NN). No significant differences in mean ages were found between the two sexes. Besides, no correlation was found between sex and

Table 1. Demographic data.

\begin{tabular}{llc}
\hline Subjects & Men & Women \\
\hline Number (\%) & $23(77 \%)$ & $7(23 \%)$ \\
$\begin{array}{l}\text { Men age } \pm \text { SD (years) } \\
\quad \text { p value }\end{array}$ & $31.2 \pm 7.1$ & $32.9 \pm 6.2$ \\
Narcoleptics (\%) & \multicolumn{2}{c}{0.6} \\
Non-narcoleptic (\%) & $9(39 \%)$ & $3(42 \%)$ \\
$\quad$ Odds ratio (confidence interval) & $14(61 \%)$ & $4(58 \%)$ \\
\hline
\end{tabular}


Table 2. MSLT parameters observed in narcoleptic group and non-narcoleptic group.

\begin{tabular}{lccc}
\hline & Narcoleptics & Non-Narcoleptics & $p$ value \\
\hline Subjects & $12(40 \%)$ & $18(60 \%)$ & - \\
Mean sleep time (min) & $16 \pm 6.3$ & $10.5 \pm 7.5$ & $<0.0001$ \\
Mean sleep onset latency (min) & $2.0 \pm 2.2$ & $7,2 \pm 6.0$ & $<0.001$ \\
Mean REM sleep latency (min) & $3.2 \pm 3.1$ & $6.9 \pm 3.7$ & 0.021 \\
Frequency of dreams reported in each series & $56.9 \%$ & $28.4 \%$ & 0.0009 \\
Frequency of dreams reported in the NREM sleep series & $21.87 \%$ & $75 \%$ & 0.0001 \\
\hline
\end{tabular}

Table 3. MSLT parameters observed for each type of series analyzed.

\begin{tabular}{lccccc}
\hline & $\mathrm{n}^{\circ}$ & $\%$ & $\begin{array}{c}\text { Mean sleep } \\
\text { time } \pm \text { SD } \\
(\mathrm{min})\end{array}$ & $\begin{array}{c}\text { Mean sleep } \\
\text { latency } \pm \text { SD } \\
(\mathrm{min})\end{array}$ & $\begin{array}{c}\text { Mean REM } \\
\text { latency } \pm \text { SD } \\
\text { (min) }\end{array}$ \\
\hline Series with sleep & 126 & 100 & - & - & - \\
with dreams & 56 & 44.4 & $15.2 \pm 4.9$ & $3.3 \pm 3.4$ & $4.0 \pm 3.2$ \\
without dreams & 70 & 55.6 & $14.2 \pm 6.8$ & $6.0 \pm 6.3$ & $3.0 \pm 3.8$ \\
$\begin{array}{l}\text { p value } \\
\text { with REM sleep }\end{array}$ & - & - & 0.083 & 0.017 & 0.200 \\
without REM sleep & 42 & 33.3 & $16.4 \pm 3.8$ & $2.3 \pm 2.6$ & $3.8 \pm 3.4$ \\
$\begin{array}{l}\text { p value } \\
\quad \text { with dreams during REM }\end{array}$ & 84 & 66.7 & $13.7 \pm 6.7$ & $6.1 \pm 5.9$ & - \\
$\quad$ with dreams during non-REM & 25 & 29.8 & $13.0 \pm 5.1$ & $4.4 \pm 4.0$ & - \\
p value & - & - & 0.0021 & $<.0 \pm 3.2$ \\
\hline
\end{tabular}

p revalence of narcolepsy (Odds ratio $=0.86$ with confidence interval $=0.15$ to 4.8 ), as reported in Table 1. Within the $\mathrm{N}$ group, a mean sleep time of $16 \pm 6.3$ min was observed, while for the NN group it was $10.5 \pm 7.5 \mathrm{~min}(\mathrm{p}<0.0001)$. Furthermore, the mean sleep onset latency was significantly shorter $(p<0.001)$ in the $\mathrm{N}$ group (2.0 $\pm 2.2 \mathrm{~min})$ than the $\mathrm{NN}$ group (7.2 \pm 6.0 min). A similar pattern was also observed for the mean REM sleep latency $(3.2 \pm 3.1$ and $6.9 \pm 3.7 \mathrm{~min}, \mathrm{~N}$ and NN group, respectively) $(p=0.021)$. The frequency of dreams reported was significantly greater in the $N(56.9 \%)$ than the NN group (28.4\%) $(p=0.0009)$. A significantly higher frequency of dreams re p orted in the NREM sleep series was observed in the NN group (75\%), compared to the $N$ group $(21.87 \%)(p=$ 0.0001) (Table 2).

F rom the total of 146 series obtained, sleep was observed in 126 (86.3\%). NREM and REM sleep laten- cies, as well as sleep time of series with and without dreams are reported in Table 3.

\section{DISCUSSION}

Within our study sample, consisting essentially of individuals with excessive daytime sleepiness, a 40\% prevalence of narcoleptic-compatible patients was obsened. Mean sleep latency of patients from the $\mathrm{N}$ $g$ roup (2.0 $\pm 2.2 \mathrm{~min}$ ) was considerably lower than the 5 -min minimum frequently employed in other studies $^{2,4}$, as well as the values observed in the NN group (7.2+6 min). Similarly, significant diffe rences in mean REM sleep latency were also seen between the $\mathrm{N}(3.2$ $\pm 3.1 \mathrm{~min})$ and the NN groups $(6.9 \pm 3.7 \mathrm{~min} ; \mathrm{p}=0.021)$. These findings seem to corroborate the notion that REM sleep mechanisms in narcoleptics are triggere d earlier than in patients with excessive daytime sleepiness of non-narcoleptic origin. 
In general, group $\mathrm{N}$ patients dreamt more, particularly during REM sleep. This result is not surprising as in these patients REM sleep seems to be more critically involved. On the other hand, neural circuits underlying REM mental activity, in addition to the activation of REM sleep itself, may be facilitated in narcoleptic patients. However, the earlier onset of REM sleep did not influence dream frequency, as REM sleep latency of series with and without dreams were similar. Small sample size, however, may have influenced this result. REM duration, continuity or stability in each series may, in fact, be more directly related to the onset of dreams. This issue should be further investigated employing a greater number of subjects. Among the non-narcoleptic patients, on the other hand, dreams were predominantly reported to occur during NREM sleep series (75\%). Changes in REM sleep onset mechanisms were not apparent in this group.

Mental activity, including the oniric type, has been report for over 50 years. In fact, dreams are reported by $5-10 \%$ of individuals awoken during NREM sleep ${ }^{14,22}$, although this percentage is thought to be as high as $50 \%$. In the present study, dreams were registered in 25 of the 84 series in which REM sleep had not been electrographically identified (29.8\%). In general, such dreams are said to be less complex and vivid than those occurring during REM sleep ${ }^{14,15,19,22,23}$. This result is corroborated by previous studies describing the "covert REM sleep" mod$\mathrm{el}^{24}$. The later conceptualizes the existence of an intermediate sleep stage; i.e. a transitional sleep period where REM sleep elements (e.g. changes in physiological parameters, eye movements, oniric activity) may be detected during a polysomnographically characterized NREM period. Several factors, such as the absence of REM when it is physiologically expected (i.e. after approximately $90 \mathrm{~min}$ of sleep), the influence of certain compounds (reserpine, barbiturates) or even the transitional period between wakefulness and stage 1 sleep, may contribute to the advent of this "intermediate sleep".

On the other hand, REM sleep pressu re itself (secondary to sleep disorders or deprivation) is known to induce the transition from "covert REM sleep" stage to a full REM sleep ${ }^{24}$. As both groups in the present study (i.e. $\mathrm{N}$ and $\mathrm{NN}$ ) had daytime sleepiness complaints, a similar pressure upon total sleep time was expected. In addition, patients from the $\mathrm{N}$ group also suff e red specific pressure from REM sleep, typical of a narcoleptic condition, which were not observed in the NN patients. Therefore, in the later group, REM sleep may not have had sufficient pressure to favor the transition of the "intermediate state" into a polysomnographically defined REM stage, which in turn could account for the greater NREM dreaming frequency reported $(75 \%)$.

Furthermore, the advent of dreams during REM sleep is known to be associated with stimulation of dopaminergic pathways in the ventro-medial frontal lobe region ${ }^{14}$. Theoretically, within an excessive daytime sleepiness population, the activation of such circuits may also happen during NREM sleep, as the physiological mechanisms are due to the direct interaction of anatomical and functionally proximate neural pathways (brainstem, basal region of the frontal lobe) ${ }^{14,15,19}$. Thus, beyond certain intensity of sleep pressure, features of NREM sleep may also possibly activate dreaming circuitry during NREM sleep itself. In the general population, however, dreaming during NREM sleep may be considered part of a physiological process ${ }^{14}$.

In conclusion, the present study demonstrated that narcoleptic-compatible patients had longer sleep time, faster sleep onset, earlier REM onset and $\mathrm{d}$ reamt more than subjects with daytime sleepiness of a diffe rent origin in the MSLT. The later group, on the other hand, demonstrated a significantly higher $d$ reaming frequency during NREM sleep. Such findings may be explained, in part, by the "covert REM sleep" model ${ }^{15,23}$. Dreaming during NREM sleep may be part of a homeostatic mechanism in cases of sleep disorders or deprivation. Taken together, these results indicate that routine investigation of dreaming, following each MSLT series, as well as the exact moment they occur (NREM, REM), may contribute in a more objective way to the differential diagnosis between na rcolepsy and excessive daytime sleepiness of a distinct etiology.

\section{REFERENCES}

1. Aldrich MS, Chervin RD, Malow BA. Value of the multiple sleep latency test (MSLT) for the diagnosis of narcolepsy. Sleep 1997;20:620-629.

2. Baker MJ, Bendadis SR. Narcolepsy, 2004. (Acessed February 20,2005 at http:/ / www.emedicine.com/neuro/topic522.htm.)

3. Douglas NJ. “Why am I sleepy?" sorting the somnolent. Am J Respir Crit Care Med 2001;163:1310-1313.

4. Green PM, Stillman MJ. Narcolepsy: signs, symptoms, differential diagnosis, and management. Arch Fam Med 1998;7:472-478.

5. Sto resG. Recognition and management of narcolepsy. Arch Dis Child 1999;81:519-524.

6. Bendadis SR, Wolgamuth BR, Perry MC, Dinner DS. Dreams and rapid eye movement sleep in the multiple sleep latency test. Sleep 1995; 18:105-108.

7. Baumann CR, Basseti CL. Hypocretins (orexins) and sleep-wake disorders. Lancet Neurol 2005;4:673-680. 
8. Nishino S, Kanbayashi T. Symptomatic narcolepsy, cataplexy and hypersomnia, and their implications in the hypothalamic hypocretin/orexin system. Sleep Med Rev 2005;9:269-310.

9. Eiser AS. Physiology and psychology of dreams. Semin Neurol 2005; 25:97-105.

10. Lehtonen J. Origins of dreaming. Trends Cogn Sci 2002;6:23-30.

11. Reiser MF. The dream in contemporary psychiatry. Am J Psychiatry 2001;158:351-359.

12. Russo MB. Normal sleep, sleep physiology, and sleep deprivation: general principles, 2005. (Acessed February 20,2005, at http: / / www.emedicine.com/neuro/topic444.)

13. Schwartz S, Maquet P. Sleep imaging and the neuro-psychological assessment of dreams. Trends Cogn Sci 2002;6:23-30.

14. Solms M. Dreaming and rem sleep are controlled by diff e rent brain mechanisms. Behav Brain Sci 2000;23:843-850.

15. Takeuchi T, Miyasita A, Inugami M, Yamamoto Y. Intrinsic dreams are not produced without rem sleep mechanisms: evidence through elicitation of sleep onset REM periods. J Sleep Res 2001;10:43-52.

16. Cartwright RD, Lloyd SR. Early REM sleep: a compensatory change in depression? Psychiatry Res 1994;51:245-252.

17. Niiyama Y, Shimizu T, Abe M, Hishikawa Y. Phasic eeg activities asso- ciated with rapid eye movementes during REM sleep in man. J Neuropsychiatry Clin Neurosci 2002;14:283-288.

18. Peterson ND, Henke PG, Hayes Z. Limbic system function and dream content in university student. Psychiatry Clin Neurosci 2002;56:345-354.

19. Gottesman C. The neurochemistry of waking and sleeping mental activity: the disinhibition-dopamine hipotesis. Am J Psychiatry 2002;159:459.

20. Lucchesi LM, Pradella-Hallinan M, Lucchesi M, Moraes WAS. O sono em transtornos psiquiátricos. Rev Bras Psiquiatr 2005;27:27-32.

21. Americam Academy of Sleep Medicine. The internatinal classification of sleep disorders, revised, 2005. (Acessed January 28,2006, at http:/ / www.absm.org/PDF/ICSD.pdf).

22. Suzuki H, Uchiyama M, Tagaya $H$, et al. Dreaming during non-rapid eye movement sleep in the absence of prior rapid eye movement sleep. Sleep 2004;27:1486-1490.

23. Nielsen T, Stenstrom P, Takeuchi T, et al. Partial REM-sleep deprivation increases the dream-like quality of mentation from REM sleep and sleep onset. Sleep 2005;28:1083-1089.

24. Nielsen TA. A review of mentation in REM and NREM sleep: "covert" REM sleep as a possible reconciliation of two opposing models. Behav Brain Sci 2000;23:851-866. 